\title{
POTENCJAŁ GIER MIEJSKICH I QUESTINGU JAKO NARZĘDZI MARKETINGU TERYTORIALNEGO - ANALIZA NA PRZYKLADZIE DZIAŁAŃ RZESZOWA
}

\begin{abstract}
Autorzy artykułu analizują gry miejskie i questing jako innowacyjne i atrakcyjne narzędzia marketingu terytorialnego. Dzięki wywołaniu autentycznych emocji i zaangażowania wśród klientów narzędzia te stwarzają korzystną sytuację sprzedażową oraz budują pozytywny wizerunek marki. Autorzy opisują możliwości, jakie daje zastosowanie storytellingu w budowaniu pozytywnego stosunku emocjonalnego do produktu, usługi, a zwłaszcza jednostki terytorialnej - regionu, miasta, wsi, oraz przedstawiają zasady jego poprawnego stosowania. Następnie przedstawiają konstrukcję i możliwości zastosowania questingu oraz gier miejskich jako skutecznych, innowacyjnych i tanich sposobów na promocję miast. Uwzględniając cele marketingu terytorialnego, autorzy dokonują podziału gier miejskich i scenariuszy questingowych na trzy kategorie: opowiadające o mieście i jego historii, nieopowiadające o mieście i jego historii, lecz nawiązujące do pewnego szerszego kontekstu oraz gry miejskie i questing stricte rozrywkowy. Analizę poszczególnych kategorii przeprowadzono na przykładzie miasta Rzeszów, które było areną licznych gier miejskich; ponadto miasto oferuje własne scenariusze questingowe. Dostępne scenariusze questingowe scharakteryzowano pod kątem ich budowy, grupy docelowej oraz potencjału, jaki niosą dla budowy korzystnego wizerunku miasta. Gry miejskie zostały opisano według podobnego klucza z uwzględnieniem środków, jakie zastosowano w celu ich przeprowadzenia. Autorzy konkludują, że gry miejskie i scenariusze questingowe są wartościowym i oryginalnym sposobem promocji jednostek terytorialnych, gdyż są tanie w realizacji, pozwalają na odkrycie (czasem nawet na nowo) danego miasta poprzez wykorzystanie wyjątkowych elementów oraz jego historii, aktywizują lokalną społeczność oraz wykazują wartości edukacyjne.

Słowa kluczowe: storytelling, gra miejska, questing, marketing terytorialny
\end{abstract}

\section{WPROWADZENIE}

Intensywna eksploatacja narzędzi marketingowych i zacięta konkurencja pomiędzy markami doprowadziła do sytuacji, w której zarówno przedsiębiorstwa sektora prywatnego, jak i publicznego, organizacje pożytku publicznego i partie polityczne poszukują nowatorskich rozwiązań w komunikacji z odbiorcą (klientem, wyborcą itd.). Dąży się do zaoferowania klientom ciekawych, nietuzinkowych form promocji, które nie tylko skupią ich uwagę, ale będą również dla odbiorcy formą rozrywki, a w konsekwencji wywołają pozytywne skojarzenia związane z marką lub produktem. Nie bez znaczenia jest także natłok informacji, jakim poddawana jest jednostka każdego dnia, oraz efekt attentioncash,

\footnotetext{
${ }^{1}$ Grzegorz Droba, doktorant, Instytut Socjologii, Wydział Socjologiczno-Historyczny, Uniwersytet Rzeszowski, ul. Rejtana 16C, 35-310 Rzeszów

${ }^{2}$ Sabina Przepióra, doktorantka, Instytut Socjologii, Wydział Socjologiczno-Historyczny, Uniwersytet Rzeszowski, ul. Rejtana 16C, 35-310 Rzeszów, e-mail: sabina.przepiora@gmail.com, tel.: 602624593 (autor korespondencyjny).
} 
który determinuje w komunikacji masowej poszukiwanie coraz to skuteczniejszych oraz bardziej efektywnych strategii marketingowych ${ }^{3}$. W świecie, w którym panują szum informacyjny i nakładające się na siebie komunikaty, nawet największe marki mają trudność z efektywną komunikacją z odbiorcami. Przekaz promocyjny jednostek terytorialnych, takich jak regiony, miasta i mniejsze miejscowości, również jest poddany wspomnianym procesom i tak samo jak korporacje poszukują one rozwiązań, które zapewnią im rozpoznawalność i wyróżnienie się na tle konkurencji. Taki stan rzeczy sprawił, że coraz większą popularność zyskują gry miejskie.

Trend ten widać w „Marketingowej Strategii Polski w Sektorze Turystyki w latach 2012-2020”, która podkreśla znaczenie „3× E” ( education, entertainment, excitement) jako istotnego czynniku rozwoju współczesnej turystyki. Wśród form turystyki, które zaczynają się rozwijać w Polsce, wymieniono między innymi questing, formy zwiedzania miast z wykorzystaniem gier tematycznych, turystykę muzealną, biograficzną, studyjną, kulinarną, kultury ludowej, literacką i filmową oraz tanatoturystykę ${ }^{4}$. Odbiorcy (mieszkańcy, turyści i inwestorzy), oceniając atrakcyjność danego miejsca, nie opierają się na statystykach, danych opisujących infrastrukturę czy łatwość dostępu do służby zdrowia. Hasła promocyjne, wyszukane logotypy i kampanie reklamowe również nie są w stanie sprawić, że mieszkaniec czy turysta odwiedzający daną miejscowość poczuje prawdziwe emocje. Wzbudzenie związku emocjonalnego ułatwia sprzedaż oraz buduje relację, czyniąc z uczestników odbiorców zaangażowanych, przeżywających przekaz i zaszczepiających zainteresowanie w innych.

\section{QUESTING I GRY MIEJSKIE}

Gry miejskie polegają na wykorzystaniu przestrzeni danego miasta, czyniąc z niej planszę gry, w ramach której gracze (uczestnicy) rozwiązują przydzielone im zadania i rywalizują z innymi. Najczęściej spotykane plansze przybierają płaską formę, zazwyczaj przedstawiającą mapę, która przechowuje przeszłość, teraźniejszość i przyszłość danego miejsca. Co za tym idzie - nie tylko odwzorowują przestrzeń rzeczywistą, ale także tworzą jej nowe, dodatkowe wymiary ${ }^{5}$. Zazwyczaj o wyniku w grze miejskiej decydują: czas zakończenia zadań (im szybciej uczestnicy je ukończą, tym lepiej są oceniani), liczba lub też waga rozwiązanych zadań oraz odnalezienie ukrytych, specjalnie punktowanych elementów (np. dodatkowych zadań lub ukrytych nagród). Gry miejskie często są wzbogacane o elementy RPG ( role-playing games), a także łączą w sobie elementy happeningów, gier komputerowych, podchodów harcerskich oraz flashmobów. Dobrze skonstruowany scenariusz gry miejskiej pozwala zawodnikom na wykorzystanie zarówno umiejętności praktycznych, jak i wiedzy teoretycznej, dając zarazem sposobność do pozyskania nowych informacji i odkrywania nieznanych wcześniej ,zakamarków” przestrzeni miejskiej ${ }^{6}$. Gry miejskie przechowują przeszłość i pozwalają przenosić się do niej, a równocześnie wybiegając w przyszłość, tworzą teraźniejszość, dzięki czemu fabuła

\footnotetext{
${ }^{3}$ E. Mistkiewicz, Markeing narracyjny. Jak budować historie, które sprzedaja, Helion, Gliwice 2011, s. 16.

${ }^{4}$ MarketingowaStrategia Polski w Sektorze Turystyki w latach 2012-2020, red. B. Walas, Polska Organizacja Turystyczna, Warszawa 2011, s. 10.

${ }^{5} \mathrm{~K}$. Schlögel, W przestrzeni czas czytamy. O historii cywilizacji o geopolityce, Wydawnictwo Poznańskie, Poznań 2009, s. 85.

${ }^{6}$ A.Czetwertyńska, K.Grubek, Warszawskie gry literackie, Fundacja Centrum Edukacji Obywatelskiej, Warszawa 2009.
} 
może być oparta na wydarzeniach historycznych, grze komputerowej, literaturze, filmie, ale także całkowicie wymyślonej historii.

Delia Clark i Stevena Glazer w pracy Questing: A Guide to Creating Community Treasure Hunts definiują questing jako model edukacji regionalnej (place-based education), który skupia się na odkrywaniu najbliższego otoczenia człowieka, poznawaniu i zdobywaniu wiedzy na temat dziedzictwa kulturowego i przyrodniczego przede wszystkim w skali lokalnej ${ }^{7}$. Questing umożliwia samodzielne zwiedzanie jednostki terytorialnej przy użyciu schematycznej mapy z prostymi zadaniami i wierszowanymi wskazówkami, z których uczestnik korzysta, przemierzając wyznaczoną trasę. W Polsce popularyzowany jest od 2011 r., w dużej mierze przez trenerów questingu i organizacje pozarządowe, do których należą między innymi: Agencja Public Relations Planet PR, Fundacja Best Place, Fundacja Miejsc i Ludzi Aktywnych oraz Polska Organizacja Turystyczna ${ }^{8}$. W wielu przypadkach stanowi on interesujące uzupełnienie sieci szlaków turystycznych i kulturowych, nazywanych także tematycznymi. Questing jest definiowany jako rodzaj zabawy terenowej podobnej do gry miejskiej, którego celem sąinnowacyjna prezentacja, udostępnianie i interpretacja dziedzictwa kulturowego i przyrodniczego. Zasadnicza różnica pomiędzy questingiem a grą miejską polega na tym, że questing może być traktowany jako produkt samodzielny, niewymagający nadzorowania i kontroli ze strony organizatorów; raz opracowane scenariusze questingu wystarczy opublikować i zachęcić do samodzielnego zwiedzania przez wszystkich zainteresowanych ${ }^{9}$.

Questing miejski polega na odkrywaniu dziedzictwa kulturowego i przyrodniczego miejsca, w którym się odbywa, poprzez tworzenie nieoznakowanych szlaków, którymi uczestnicy przemieszczają się dzięki informacjom zawartym w różnego rodzaju wskazówkach. Jego istotą jest rozwijanie poczucia tożsamości miejsca, szukanie wyjątkowości w pozornie zupełnie zwyczajnych przestrzeniach, upowszechnianie niepowtarzalnych miejsc wyróżniających się krajobrazem, przyrodą czy też dziedzictwem kulturowym, a także kierowanie się przy tym względami czysto rozrywkowymi. W aglomeracjach, będących znanymi ośrodkami turystycznymi, questing stwarza uczestnikom możliwość poznania mniej znanych obiektów i miejsc zabytkowych, położonych poza dzielnicą staromiejską koncentrującą ruch turystyczny. Warto zaznaczyć, że funkcje turystyczne oraz edukacyjne questingu wzajemnie się przenikają, a same szlaki stanowią przykład działania na rzecz rozwoju i popularyzacji turystyki kulturowej danego miejsca. Wszystko to sprawia, że ta forma turystyki wpisuje się we wcześniej już wspomniany trend „3 $\times$ E”. Tworzenie tras questingowych oraz gier miejskich jest procesem, w którym uczestniczą zarówno przedstawiciele lokalnej społeczności, dzieci, studenci, ale także pasjonaci przyrody, historii oraz kultury. Jak zauważył Philip D. Straffin, o grze możemy mówić w sytuacji, gdy: „możemy wskazać co najmniej dwóch graczy [...], każdy gracz ma do wyboru pewną liczbę możliwych strategii, wynik gry jest determinowany przez kombinację strategii wybranych przez poszczególnych graczy i każdemu możliwemu wynikowi gry odpowiada zestaw wypłat dla poszczególnych graczy” ${ }^{10}$. Do kreowania i późniejszego

\footnotetext{
${ }^{7}$ D. Clark, S. Glazer, Questing. A Guide to Creating Community Treasure Hunts, University Press of New England, Lebanon 2004, s. 1-2.

${ }^{8}$ Ł. Wilczyński, Questing - nowy trend w turystyce, [w:] B. Włodarczyk, B.Krakowiak, J. Latosińska, Kultura i turystyka. Wspólna droga, Regionalna Organizacja Turystyczna Województwa Łódzkiego, Łódź 2011, s. 55. 
rozwijania gier wykorzystywane są informacje dotyczące danego miejsca - zarówno te naukowe i specjalistyczne, jak również informacje dotyczące historii, legend czy anegdot. W trakcie projektowania tras wypraw wykorzystuje się następujące obiekty i miejsca ${ }^{11}$ :

1. budynki użyteczności publicznej, czyli poczty, muzea;

2. budynki prywatne, na przykład sklepy, restauracje;

3. obiekty związane z kulturą i historią, między innymi pomniki, stare kościoły czy zabytki;

4. miejsca szczególnie lubiane przez lokalne społeczności;

5. miejsca związane ze znanymi osobami, na przykład artystami, postaciami historycznymi;

6. geomorfologię terenu, między innymi wzgórza, doliny oraz inne zjawiska geologiczne;

7. rzeki, strumienie, jeziora i stawy;

8. lasy, parki miejskie, parki narodowe i krajobrazowe;

9. charakterystyczne elementy przyrodnicze, czyli miejsca występowania specyficznych roślin, pomniki przyrody, rezerwaty, stare drzewa.

\section{OPOWIEŚĆ PODSTAWĄ GRY}

Każdy lubi dobre opowieści, szczególnie gdy są one ciekawie przekazane. Interesująca historia potrafi zmienić percepcję danej osoby, miejsca, firmy, partii, stowarzyszenia, regionu, a nawet kraju ${ }^{12}$. Dodatkowo stanowią one swego rodzaju formę wymiany w relacjach międzyludzkich; już w czasach średniowiecza zapisy, które miały formę przekazywanych narracji wpływały i jednocześnie kształtowały świadomość zbiorową społeczeństwa ${ }^{13}$. Historie są doskonałym narzędziem nauki, zapamiętywania, wiązania faktów i poznawania kontekstu danych sytuacji. Pomagają zrozumieć ludzkie działania i motywacje, mogą się również stać inspiracją do konkretnych działań każdej jednostki. Dzięki ładunkowi emocjonalnemu, jaki zawarty jest w każdej opowieści, zostają one w pamięci dłużej niż suche fakty, liczby czy definicje. Techniki narracji, mimo że od lat nie uległy znacznym zmianom, potrafią opanować chaos informacyjny, czyniąc z opowieści narzędzie budowy identyfikacji i przynależności, a zarazem inspirację do dzielenia się emocjami oraz magią miejsca $\mathrm{z}$ innymi ${ }^{14}$. $\mathrm{Z}$ tych powodów marketing narracyjny ${ }^{15}$ zyskuje coraz bardziej na popularności i jest konsekwentnie wdrażany zarówno przez największe marki, jak i jednostki terytorialne na całym świecie. Storrytelling to sztuka używania słów oraz metafor w taki sposób, by zobrazowały one pewną ideę czy zamysł w sposób pobudzający wyobraźnię odbiorcy i poruszający jego emocje. Paweł Tkaczyk jako

\footnotetext{
${ }^{11}$ K. Florys, B. Kazior, Badanie obszaru LGR w zakresie możliwości wdrożenia questingu na obszarze Lokalnej Grupy Rybackiej Stowarzyszenia Dolina Karpia, Fundacja Miejsc i Ludzi Aktywnych, Kraków 2011, s. 4-5.

${ }^{12}$ E. Mistkiewicz,op. cit., s. 43.

${ }^{13}$ Ibidem, s. 45.

${ }^{14}$ Ibidem, s. 102.

${ }^{15}$ Marketing narracyjny jest jednym z podstawowych narzędzi brandingu, polega on na przekazywaniu wartości danej marki w przystępny dla odbiorcy sposób za pomocą odpowiednio skonstruowanych historii i opowieści.
} 
podstawowe zasady, które muszą zostać spełnione, by opowieść spełniła swoją funkcję, wskazał 16 .

1. opowiedzenie konkretnej historii konkretnego bohatera;

2. opowiedzenie o konflikcie, który wyrażony jest przez pozbawienie bohatera czegoś, co bardzo chce mieć, oraz o dążeniu i przezwyciężaniu spotykanych na drodze trudności;

3. zaangażowanie emocji odbiorcy poprzez odwołanie się do koncepcji monomitu (należy dać bohaterowi opowieści towarzyszy, oszustów, których spotyka na swojej drodze, ale także cel);

4. w trakcie opowieści należy używać charakterystycznych markerów, dzięki którym opowieść odróżni się od innych i zostanie zapamiętana.

Z kolei Eryk Mistewicz w swojej publikacji Marketing narracyjny. Jak budować historie, podaje pięć elementów, którymi powinna cechować się dobra narracja w kontekście sprzedaży. Należą do nich: pasja, personalizacja, antagonistyka, chwila świadomości oraz zwycięstwo. Scenariusz gry miejskiej czy questingu ułożony według tych zasad ma większą moc oddziaływania na uczestników, a w konsekwencji buduje silniejszą więź emocjonalną.

\section{QUESTING I GRY MIEJSKIE W RZESZOWIE}

Podobnie jak inne jednostki terytorialne, Rzeszów również korzysta z działań marketingowych opartych na questingu czy formule gry miejskiej. Jedną z mocnych stron tego typu przedsięwzięć jest fakt, że questing i gry miejskie nie muszą być inicjowane przez administrację, lecz mogą powstawać spontanicznie jako efekt działalności organizacji pozarządowych, zrzeszeń, stowarzyszeń, a nawet pojedynczych mieszkańców miasta. Rola jednostek odpowiedzialnych za marketing terytorialny (na szczeblu miasta, powiatu czy województwa) może ograniczyć się w tym wypadku jedynie do koordynacji przedsięwzięć, udzielenia pomocy merytorycznej lub udostępnianiu własnych kanałów komunikacyjnych w celu wzmocnienia ich promocji. Gry miejskie i zrealizowane w Rzeszowie questingi można podzielić na trzy podstawowe kategorie:

1. opowiadające o mieście i jego historii;

2. nieopowiadające o mieście $\mathrm{i}$ jego historii, lecz nawiązujące do pewnego szerszego kontekstu, w którym są umiejscowione;

3. stricte rozrywkowe.

Każda z wymienionych kategorii ma własną narrację i odwołuje się do innych emocji. Niezależnie jednak od swojej specyfiki spełnia podstawowy cel strategiczny zaciekawienie odbiorców i zachęcenie ich do eksploatacji miejskiej przestrzeni.

\section{GRY MIEJSKIE I QUESTY OPOWIADAJĄCE O MIEŚCIE}

Wydział Promocji i Współpracy Międzynarodowej Urzędu Miasta Rzeszowa przy współpracy z firmą Planet PR przygotował trzy scenariusze wypraw bezpośrednio nawiązujących do historii miasta. Jest to zatem questing oficjalny, dostępny bezpłatnie w Ratuszu, punktach informacyjnych oraz na specjalistycznej stronie WWW (w formie

${ }^{16} \mathrm{P}$. Tkaczyk, Co storytelling może dać marce?, „Marketing w praktyce”, www.essentis.pl/czytelnia/ekspert- 
ulotki bądź pliku .pdf do pobrania z witryny) ${ }^{17}$. Pierwszą z nich są Opowieści rzeszowskiego kupca, scenariusz mający na celu przybliżenie historii lokacji i rozwoju miasta oraz stworzenie średniowiecznego klimatu jarmarków. „Jej trasa wyznaczona jest w rynku oraz okolicznych ulicach, przez co przybliża detale architektury miejskiej m.in. kościołów i kamienic. Uczestnicy wyprawy dowiadują się, jak wyglądał Rzeszów w XVIII wieku, i poznają historię ratusza" ${ }^{18}$. Uczestnicy questingu podążają szlakiem wyznaczonym przez rymowaną opowieść kupca, uzupełniając w niej brakujące słowa i zbierając litery składające się na hasło końcowe. Ostatni punkt questu znajduje się w holu Podziemnej Trasy Turystycznej, gdzie na uczestników czeka „skarb” oraz możliwość podbicia oficjalną pieczątką ulotki jako dowód ukończenia zadania. Nutki historii w rzeszowskich pomnikach to tytuł drugiego oficjalnego questu. Jego budowa i sposób narracji są bardzo zbliżone do Opowieści rzeszowskiego kupca, jednak w tym wypadku uczestnicy prowadzeni są szlakiem turystycznym przebiegającym w sąsiedztwie znanych pomników, tablic pamiątkowych i budynków. Sens całego questu, a zarazem styl jego narracji najlepiej oddaje pierwszy akapit scenariusza:

„Szlak rzeszowskich pomników rozpoczniesz od tego

Właśnie monumentu - Czynu Rewolucyjnego.

Łącznie odwiedzisz kilkanaście pomników; dodaj jeszcze do nich

Trzydzieści sześć dzieł sztuki misternie rzeźbionych, co w Rzeszowie stoi” ${ }^{19}$.

Podobnie jak w wypadku pierwszego opisywanego scenariusza uczestnicy zabawy uzupełniają brakujące słowa w opowieści (odnoszące się do pomników i budynków) w celu odnalezienia finalnej „nutki” - obiektu poszukiwań. W roku 2012 twórcy scenariuszów z firmy Planet PR przygotowali do każdego z opisanych questów specjalne zadania praktyczne, czyniąc $\mathrm{z}$ nich de facto grę miejską. Urozmaicone questy były jedną z głównych atrakcji zaoferowanych zwiedzającym Rzeszów uczestnikom konferencji InternetBeta $2012^{20}$. Trzeci z dostępnych scenariuszy Legendy Rzecha stanowi wariacje dwóch pozostałych questów.

Historia Rzeszowa - rowerowa gra miejska została przygotowana z okazji Święta Cyklicznego w 2012 roku przez Stowarzyszenie na Rzecz Aktywności SpołecznoArtystycznej. Jak wyjaśnił założenia scenariusza Grzegorz Chudzik, Prezes Stowarzyszenia: „Fabułę wymyśliliśmy, studiując losy Leopolda Lisa-Kuli i badając historię Strzelców, do których należał" "21. Zawodnicy poruszali się głównie po terenie Starego Miasta i odwiedzali miejsca związane z postacią Lisa-Kuli, napotykając członków Związku Strzeleckiego „Strzelec”, ucharakteryzowanych w przekonujący sposób. Trasa gry wiodła między innymi obok II Liceum Ogólnokształcącego (gdzie Lis-Kula uczęszczał), przez

\footnotetext{
${ }^{17}$ Questing, http://questing.pl/t/rzeszow (dostęp: 12.05.2014)

${ }^{18} \mathrm{Gdzie}$ questować?, http://questing.pl/gdzie-questowac/quest-opowiesci-rzeszowskiego-kupca/ (dostęp: 12.05.2014).

${ }^{19}$ Pora ruszyć na poszukiwania, http://www.rzeszow.pl/turystyka/questing-pora-ruszyc-na-poszukiwania/nutkihistorii-w-rzeszowskich-pomnikach (dostęp: 12 maja 2014).

${ }^{20}$ Questing na InternetBeta2012, http://questing.pl/aktualnosci/questing-na-internet-beta-2012/ (dostęp: 12.05.2014)

${ }^{21}$ Stowarzyszenie
http://www.icimss.edu.pl/tkt/index.php?link= artysta\&id=583 [dostęp: 12.05 .2014 r.].
} 
Olszynki (gdzie wiosną 1911 r. założył tajne stowarzyszenie), cmentarz na Pobitnem (gdzie odbył się jego pogrzeb), kończąc się przy tablicy pamiątkowej, poświęconej jego imieniu $^{22}$. Sama gra została zaprojektowana na czas około dwóch godzin, a uczestnicy przemieszczali się na jej trasie za pomocą rowerów. Gra została oparta na popularnej formule AlleyCat, oznaczającej, że uczestnicy rywalizacji musieli dotrzeć do wyznaczonych na mapie punktów, w których wykonywali zadania specjalne.

\section{GRY MIEJSKIE NIEOPOWIADAJACE O MIEŚCIE}

Na terenie Rzeszowa rozegrano również gry miejskie nieopowiadające bezpośrednio o mieście i jego historii, lecz odwołujące się do pewnego szerszego kontekstu zrozumiałego dla uczestników (mieszkańców i turystów). Szerszym kontekstem gry miejskiej lub questu może być na przykład epizodyczna rola miasta w ogólnokrajowym wydarzeniu, jego położenie w konkretnym regionie lub przynależność do organizacji czy stowarzyszenia zrzeszającego jednostki terytorialne. Przykładem gry miejskiej bazującej na tego typu narracji jest gra Trans Press 2013, rozegrana w Rzeszowie 1 czerwca 2013 r. Gra była jedną z pięciu gier miejskich, zorganizowanych w ramach Programu Współpracy Transgranicznej Rzeczpospolita Polska Republika Słowacka 2007-2013 przy współpracy z „Gazetą Wyborczą”; pozostałe gry odbyły się w Nowym Sączu, Bielsku-Białej oraz miejscowościach położonych na Słowacji - w Zylinie i Preszowie ${ }^{23}$. Projekt częściowo sfinansowano ze środków Unii Europejskiej w ramach Europejskiego Funduszu Rozwoju Regionalnego. Celem przedsięwzięcia było przybliżenie uczestnikom zabawy topografii i historii terenów polsko-słowackiego pogranicza oraz zadań realizowanych w ramach Programu Współpracy Transgranicznej. Zawodnicy wcielali się w rolę dziennikarzy zbierających materiały do wybrakowanego, pierwszego numeru gazety - „Kuriera transgranicznego". Grupą docelową gry były rodziny z dziećmi w wieku do czternastu lat, co nie wykluczało jednak możliwości zgłoszenia drużyny składającej się z przedstawicieli dowolnej kategorii wiekowej. Drużyny mogły się składać z dwóch do trzech zawodników. Z oficjalnych materiałów przygotowanych na potrzeby gry można było się dowiedzieć, że „podczas pięciogodzinnej zabawy czekają na Was skomplikowane zadania wymagające sporej wyobraźni, przydatne kursy, nietypowe prace redakcyjne i zdarzenia losowe, o których poinformujemy Was sms-em. Sami ułożycie swoją trasę podróży i wybierzecie zadania, które chcielibyście wykonać" ${ }^{24}$. Kolejne stacje, czyli punkty kontrolne gry, były obsadzone przez organizatorów, którzy przekazywali uczestnikom szczegółowe informacje dotyczące zadań, kontrolowali ich wykonanie, a następnie oceniali, przyznając punkty - w tym wypadku były to ,eurozłote”, czyli fikcyjna waluta. O zwycięstwie decydowały liczba zdobytych „eurozłotych” oraz czas, w którym drużyna zakończyła przygotowana trasę. Najmocniejszą stroną przeprowadzonej gry była różnorodność przygotowanych zadań, wymagających zarówno aktywności fizycznej, jak i umysłowej oraz zaangażowanie wielu osób przy obsłudze stanowisk. Niestety scenariusz gry nie przewidywał alternatywnych rozwiązań, które mogłyby zostać zastosowane w wypadku złej pogody (wszystkie stacje znajdowały się w przestrzeni niezadaszonej). W związku z obfitymi opadami

\footnotetext{
${ }^{22}$ Cykliczna gra miejska, http://www.rzeszow.roweres.pl/index.php/mapa-stacji/156-wito-cykliczne.html (dostęp: 12.05.2014).

${ }^{23}$ PL-SK 2007-2013, http://pl.plsk.eu/index/ (dostęp: 12.05.2014).

${ }^{24}$ Gra miejska TRANS PRESS 2013!, http://pl.plsk.eu/news/?lang_id=3\&id_news=1198 (dostęp: 12.05.2014).
} 
deszczu niektóre zadania były wyjątkowo utrudnione, co spowodowało liczne wycofywanie się drużyn z rywalizacji. W wydarzeniu wzięło udział około 20 drużyn, jednak nie są to dane oficjalne (organizatorzy nie byli również w stanie podać liczby drużyn, które ukończyły grę). Należy podkreślić, że gra została ciekawie przygotowana, a jej scenariusz był rozbudowany i angażujący na wielu poziomach, spełniając zarówno cele edukacyjne, jak i rozrywkowe.

Kolejną grą odwołującą się do szerszego kontekstu (a mianowicie przynależności do Unii Europejskiej i związanymi z nią programami wspierającymi rozwój regionalny) była Europejska Gra Miejska. Wydarzenie zostało przygotowane przez Regionalny Ośrodek Debaty Międzynarodowej w Rzeszowie wspólnie z Urzędem Marszałkowskim Województwa Podkarpackiego i Urzędem Miasta Rzeszowa z okazji dziesięciolecia członkostwa Polski w Unii Europejskiej. Scenariusz gry nie korzystał z metod role-playing, skupiając się jedynie na przeprowadzeniu uczestników przez ściśle wyznaczoną trasę. Wszystkie punkty kontrolne były obsadzone przez organizatorów, którzy wprowadzali uczestników w konkretne zadanie, kontrolowali jego wykonanie, a następnie potwierdzali to specjalną pieczęcią. Wszystkie stacje zlokalizowano w okolicy Starówki w Rzeszowie, w budynkach i miejscach, które zmodernizowano lub przekształcono dzięki wsparciu finansowemu Unii Europejskiej. Zadania dotyczyły znajomości Unii Europejskiej (składu państw członkowskich, historii Unii, zasad jej funkcjonowania itd.) i przeprowadzono je w formie quizów lub uzupełnianek. Jak można było przeczytać na oficjalnej stronie internetowej organizatora: „W samej Grze udział wzięły 24 grupy, łącznie 100 osób - od kilkulatków po osoby po 50. roku życia, tak więc Grę można uznać za międzypokoleniowy event” ${ }^{25}$, jednakże biorąc pod uwagę liczbę zaangażowanych instytucji i kanałów promocji, nie można tego wyniku uznać za dobry. Chociaż gra została starannie przygotowana i zaangażowano liczny personel do jej przeprowadzenia, to najszybsze drużyny (o zwycięstwie decydowała jedynie szybkość przebycia trasy) ukończyły ją w czasie krótszym niż godzina. Zaprojektowanie tak krótkiej trasy jest niekorzystne $\mathrm{z}$ punktu widzenia jakości przedsięwzięcia, gdyż zawodnicy nie mają możliwości „wciągnięcia się” w scenariusz. Walory edukacyjne i rozrywkowe gry również nie zostały w pełni wykorzystane, gdyż drużyny, zdając sobie sprawę, że decyduje jedynie kryterium czasu (brak zróżnicowania oceny jakości wykonanego zadania), quizy i uzupełnianki wykonywały jak najszybciej, nie szukając dodatkowych informacji i nie pogłębiając ich.

\section{ROZRYWKOWE GRY MIEJSKIE}

Gry rozrywkowe mogą, jednakże nie muszą wykazywać walorów edukacyjnych, ograniczając się do swojej podstawowej funkcji, jaką jest wywołanie emocji (związanych z przestrzenią miejską). Gra rozrywkowa może się opierać niemalże na dowolnej fabule i nie musi nawiązywać do żadnych historycznych wydarzeń czy kontekstu, w którym osadzona jest jednostka terytorialna. Jako przykład tego typu gry można podać Mape Skarbów zorganizowaną przez Stowarzyszenie My Life Rzeszów w ramach studenckiego festiwalu „KultURalia” Uniwersytetu Rzeszowskiego w 2013 roku. Gra została skierowana do studentów wszystkich rzeszowskich uczelni i zgromadziła ponad 350 uczestników (podzielonych na dwu- i trzyosobowe drużyny) ${ }^{26}$. Każda z drużyn otrzymała mapę, która

\footnotetext{
${ }^{25}$ Europejska Gra Miejska, http://www.rodm-rzeszow.pl/aktualnosci,EUROPEJSKA-GRA-MIEJSKA-juz-zanami-.html (dostęp: 12.05.2014).

${ }^{26}$ KultURalia, https://www.facebook.com/kultURaliaUR (dostęp: 12.05.2014).
} 
kierowała zawodników w wyznaczone miejsca, znajdujące się w okolicy centrum Rzeszowa. Każde z miejsc zawierało wskazówkę, umożliwiającą odgadnięcie ukrytego hasła, składającego się z dziewięciu cyfr. Cyfry układały się w numer telefonu, pod który musiała zadzwonić zwycięska drużyna. „Mapa Skarbów” odróżnia się od pozostałych przykładów tym, że zastosowano kody QR, które zawierały wskazówki i informacje o nagrodach dodatkowych. Kody QR umieszczono na plakatach zawieszonych w okolicy stacji kontrolnych. O zwycięstwie decydował czas wykonania zadań, jednakże większość drużyn skoncentrowała się na zdobywaniu nagród dodatkowych (ufundowanych przez restauracje położone w centrum Rzeszowa). Fabuła gry nie zachęcała zawodników do pozyskiwania informacji na temat miasta, jednakże trasa została poprowadzona przez ciekawe, mało uczęszczane fragmenty przestrzeni miejskiej. Ciekawostką i pewnego typu innowacją były również kody QR, dotychczas niezastosowane w żadnej innej grze miejskiej w Rzeszowie. Organizatorzy gry uczyli zawodników obsługi aplikacji pozwalającej na skanowanie kodów $\mathrm{QR}$ oraz bezpłatnie udostępnili ją, tak więc każdy zawodnik mógł pobrać program na swój smartrfon. Obfitość nagród oraz wykorzystanie nowoczesnych technologii sprawiły, że gra wzbudziła silne emocje wśród zawodników.

Inną grą miejską nakierowaną stricte na rozrywkę było wydarzenie My Life Romance, zorganizowane również przez Stowarzyszenie My Life Rzeszów z okazji walentynek w 2013 roku $^{27}$. Uczestnicy gry zostali poprowadzeni trasą po klubach i restauracjach znajdujących się w centrum Rzeszowa, gdzie rozwiązywali zadania przygotowane przez członków stowarzyszenia. Czas rozwiązania zadan nie odgrywał roli, a zawodnicy nie musieli przebyć całej zaprojektowanej trasy. Punkty uzyskiwali dzięki udziałowi w konkursach oraz dzięki zakupowi dań i napojów w wyznaczonych restauracjach i klubach. Gra została zakończona o północy, kiedy to wszystkie zespoły oddały swoje karty gry ze zdobytymi punktami. Po podliczeniu punktów wyłoniono zwycięzcę, kolejne zespoły zaś walczyły o nagrody pocieszenia w konkursie tanecznym. Gra My Life Romance jako przestrzeń rywalizacji wykorzystała wyłącznie lokale prywatne, co zdecydowanie odróżnia tę grę od wszystkich innych przedsięwzięć tego typu. Jej celem była promocja rzeszowskich klubów, a w konsekwencji animacja przestrzeni centrum miasta i zachęcenie młodych mieszkańców do spędzania wolnego czasu w przestrzeniach klubowych.

\section{PODSUMOWANIE}

Questing oraz gry miejskie przyciągają uczestników możliwością rywalizacji i atrakcyjnej zabawy, pozwalając spędzić czas z rodziną i przyjaciółmi w niekonwencjonalny i ciekawy sposób. Dodatkową zaletą jest także to, że często jest to jedyna możliwość dotarcia do miejsc na co dzień niezauważalnych lub takich, do których nie ma wstępu dla każdego. Do korzyści wynikających z zastosowania gier miejskich i questingu należą:

1. odkrycie (czasem nawet na nowo) danego miasta poprzez wykorzystanie wyjątkowych elementów oraz historii, które są związane z dziedzictwem przyrodniczym i kulturowym danego miejsca;

2. aktywizacja lokalnej społeczności - nie tylko dzieci, ale także młodzieży, studentów i osób dorosłych;

${ }^{27}$ Stowarzyszenie My Life Rzeszów, https://www.facebook.com/MyLifeRzeszow (dostęp: 12.05.2014). 
3. aspekt edukacyjny;

4. promocja miasta poprzez wykorzystanie nowoczesnej formy promocji turystyki.

Questin i gry miejskie zyskują na popularności, a organy zarządzające promocją jednostek terytorialnych coraz częściej sięgają po rozwiązania tego typu. Gry miejskie czy scenariusze questingu angażują zarówno odbiorców wewnętrznych, jak i zewnętrznych, dla których są ciekawym i oryginalnym sposobem na zwiedzenie nowego miejsca. Niski koszt przeprowadzenia i szeroka grupa docelowa odbiorców czynią z gier miejskich i scenariuszy questingowych wyjątkowo ciekawe narzędzie promocji jednostki terytorialnej. Liczba dostępnych scenariuszów questingu oraz liczba przeprowadzonych gier miejskich w Rzeszowie nie jest imponująca, jednakże należy wskazać na pozytywny trend. Począwszy od roku 2012, pojawia się ich zdecydowanie coraz więcej, a raz przeprowadzone gry miejskie zmieniają się w wydarzenia cykliczne.

\section{LITERATURA}

[1] Clark D., Glazer S., Questing. A Guide to Creating Community Treasure Hunts, University Press of New England, Lebanon 2004.

[2] Czetwertyńska A., Grubek K., Warszawskie gry literackie, Fundacja Centrum Edukacji Obywatelskiej, Warszawa 2009.

[3] Florys K., Kazior B., Badanie obszaru LGR w zakresie możliwości wdrożenia questingu na obszarze Lokalnej Grupy Rybackiej Stowarzyszenia Dolina Karpia, Fundacja Miejsc i Ludzi Aktywnych, Kraków 2011.

[4] Marketingowa Strategia Polski w Sektorze Turystyki w latach 2012-2020, red.B. Walas, Polska Organizacja Turystyczna, Warszawa 2011.

[5] MistkiewiczE., Markeing narracyjny. Jak budować historie, które sprzedaja, Helion, Gliwice 2011.

[6] Schlögel K., Wprzestrzeni czas czytamy. O historii cywilizacji o geopolityce, Wydawnictwo Poznańskie, Poznań 2009.

[7] Straffin P.D., Teoria gier, Wydawnictwo Naukowe Scholar, Warszawa 2001.

[8] Wilczyński Ł., Questing - nowy trend w turystyce, [w:]B. Włodarczyk, B.Krakowiak,J. Latosińska, Kultura i turystyka. Wspólna droga, Regionalna Organizacja Turystyczna Województwa Łódzkiego, Łódź 2011.

\section{Dokumenty elektroniczne}

[1] Cykliczna gra miejska, http://www.rzeszow.roweres.pl/index.php/mapa-stacji/156-witocykliczne.html (dostęp: dnia 12.05.2014).

[2] Europejska Gra Miejska, http://www.rodm-rzeszow.pl/aktualnosci,EUROPEJSKA-GRAMIEJSKA-juz-za-nami-.html (dostep: dnia 12.05.2014).

[3] Gdzie questować?, http://questing.pl/gdzie-questowac/quest-opowiesci-rzeszowskiego-kupca/ (dostęp: dnia 12.05.2014).

[4] Gra miejska TRANS PRESS 2013!, http://pl.plsk.eu/news/?lang_id=3\&id_news=1198 (dostęp: dnia 12.05.2014).

[5] KultURalia, https://www.facebook.com/kultURaliaUR (dostęp: dnia 12.05.2014).

[6] Tkaczyk P., Co storytelling może dać marce?, „Marketing w praktyce”, www.essentis.pl/czytelnia/ekspert-radzi/293-co-storytelling-moze-dac-marce, (dostęp: dnia 12.05.2014).

[7] PL-SK 2007-2013, http://pl.plsk.eu/index/ (dostęp: dnia 12.05.2014).

[8] Stowarzyszenie na rzecz Aktywności Spoleczno-Artystycznej, http://www.icimss.edu.pl/tkt/index.php?link=_artysta\&id=583 (dostęp: dnia 12.05.2014).

[9] Questing, http://questing.pl/t/rzeszow (dostęp: dnia 12.05.2014). 
[10] Questing na InternetBeta2012, http://questing.pl/aktualnosci/questing-na-internet-beta-2012/ (dostęp: dnia 12.05.2014).

[11] Stowarzyszenie My Life Rzeszów, https://www.facebook.com/MyLifeRzeszow (dostęp: dnia 12.05.2014).

\section{THE POTENTIAL OF CITY GAMES AND QUESTING AS A TOOL OF TERRI- TORIAL MARKETING - AN ANALYSIS ON THE EXAMPLE OF THE CITY OF RZESZOW}

The authors analyze city games and questing as an innovative and attractive marketing tool.With the call of authentic emotion and engagement among customers, these tools create a win-win sales situation and build a positive brand image. The authors describe the opportunities offered by the use of storytelling in building a positive emotional relationship to the product, service, and in particular territorial unit-region, city, village, and the rules for its correct use. Taking into account the objectives of territorial marketing authors divide city games and questing scenarios into three categories: telling about the city and its history, not telling about the city and its history, but referring to a broader context and finally city games and questing that are strictly entertainment. The analysis of these categories was carried out on the example of the city of Rzeszów, which was the scene of numerous city games; moreover, the city has its own questing scenarios. Available questing scenarios and city games have been characterized in terms of their design, target group and potential to build a positive image of the city. The authors conclude by saying that city games and questing scenarios are a valuable and original way to promote territorial units, because: they are cheap to implement, they allow for a discovery of the city through the use of exceptional elements and its history, activate the local community and have educational value.

Keywords: storytelling, city games, questing, territorial marketing

\section{DOI: 10.7862/rz.2014.mmr.3}

Tekst złożono w redakcji: maj 2014

Przyjęto do druku: maj 2014 